\title{
Ônus da prova das excludentes de ilicitude no processo penal e a necessidade de rompimento com a sua matriz civilista
}

\section{Burden of proof of the exclusions of unlawfulness in the criminal process and the necessity to break with its civil origin}

\section{Rafael Fecury Nogueira ${ }^{1}$}

UNAMA e FIBRA - Belém/Pará rafaelfecury@uol.com.br

http://lattes.cnpq.br/7341684103082113

https://orcid.org/0000-0001-7055-4066

Resumo: O presente trabalho propõe uma análise crítica do tema do ônus da prova das excludentes de ilicitude no processo penal, aprofundando acerca do destinatário desse ônus, se acusação ou defesa. Tradicionalmente, no Brasil prevalece o entendimento jurisprudencial de que ônus da prova das excludentes de ilicitude incumbe ao acusado, numa equiparação dessas excludentes aos fatos impeditivos, modificativos ou extintivos do direito, próprios da matriz processual civil. A origem das teses que deram sustentação para a construção da concepção atual constituirá o mote do estudo crítico a ser empregado para se avaliar a compatibilidade da matriz civilista com as regras sobre o ônus da prova no processo penal. Para uma compreensão detida do tema, necessária a realização de um percurso histórico de aspectos dogmáticos próprios do direito processual civil e do direito penal que confluem para a presente temática, como a regra de distribuição do ônus da prova no processo civil e a evolução da teoria do crime.

Palavras-chave: Processo penal; ônus da prova; excludentes de ilicitude; processo civil.

1 Doutor e Mestre em Direito Processual Penal pela Faculdade de Direito da Universidade de São Paulo, Especialista em Direito e Processo Penal pela Universidade Estadual de Londrina. Professor de Direito Processual Penal da Universidade da Amazônia e na Faculdade FIBRA. 
ABSTRACT: The present work proposes a critical analysis about the burden of proof of the exclusion of unlawfulness in criminal procedure, researching about the responsible for it, whether prosecution or defense. Traditionally, in Brazil, the jurisprudential orientation links the burden of proof of the exclusion of unlawfulness to the defendant. This link happens because the exclusion of liability's cases is equated to the civil theory about impeding, modifying or extinguishing rights facts. The following study is focused in the origin of the theses that allowed the construction of the current conception. This method enables to compare the civil and the criminal rules concerning to the burden of proof. For a detailed understanding of the subject, it is necessary to carry out a historical course of dogmatic aspects specific to civil procedural law and criminal law that converge to the current theme, such as the rule of distribution of the burden of proof in the civil procedure and the evolution of crime's theory.

KEYWORDS: Criminal procedure; burden of proof; exclusion of unlawfulness; civil procedure.

SumÁRıO: 1. Considerações iniciais; 2. Ônus da prova; 2.1. O ônus da prova objetivo e o ônus da prova subjetivo; 3 . O ônus da prova na disciplina do código de processo penal; 4. Retroceder para compreender: análise das origens da regra do ônus da prova no processo penal a partir da normativa processual civil; 5 . A relação entre tipicidade e ilicitude na teoria do delito; 6. O ônus da prova das excludentes de ilicitude no processo penal; Conclusões.

\section{Considerações INICIAIS}

A redobrada importância que assume a questão do ônus da prova das excludentes de ilicitude no processo penal brasileiro com seus significativos reflexos na decisão judicial, impõe uma revisita a algumas consagradas concepções referentes a essa temática.

A necessidade de uma análise mais acurada sobre o tema se revela a partir da indisfarçada influência que ele ainda recebe do direito processual civil, afastando-se dos postulados jurídico-penais próprios, de forma inadequada. Essa compreensão civilista sobre o ônus da prova no processo penal equipara as excludentes de ilicitude aos fatos impeditivos, 
modificativos e extintivos do direito do autor, impondo o ônus de sua prova ao réu. Por isso a necessidade de se conformar o tema à sua matriz penal, indagando-se, a quem incumbe provar a ocorrência de uma causa excludente de ilicitude no processo penal?

A par da conceituação do ônus da prova e suas espécies, para a devida compreensão do tema, buscar-se-á sua origem a partir da análise do ônus da prova na disciplina originária do Código de Processo Penal, alcançando-se as bases de sua construção dogmática, a saber, a regra de distribuição do ônus da prova prevista no Código de Processo Civil de 1939, influenciadora da normativa processual penal. Essa análise é crucial para se constatar a consequência prática que o ônus da prova no processo civil exerce no processo penal brasileiro até hoje.

Consistindo o trabalho na análise do ônus da prova das excludentes de ilicitude, imperioso o estudo da histórica relação dogmática entre tipicidade e ilicitude (antijuridicidade), inerente à teoria do delito, para o enfrentamento mais adequado e percuciente da questão objeto do presente artigo.

Por fim, a reflexão a ser empreendida neste trabalho alcançará todos os seus consectários lógicos, como a promulgação da Lei 11.690/08, o papel das partes nesse ônus, a regra de julgamento, além da influência exercida pelo princípio da presunção de inocência como garantia fundamental refletindo, como norma probatória, diretamente no ônus probatório processual penal. Em resumo, a questão a ser aqui enfrentada revela não apenas caracteres dogmáticos atinentes ao direito processual penal, mas, sobretudo, ao direito processual civil e ao direito penal, revelando a complexidade e relevância do tema.

\section{2. ÔNUS DA PROVA}

Etimologicamente, ônus significa carga, peso, encargo ou obrigação ${ }^{2}$, devendo-se transpor esse significado, nos mesmos moldes, para a prova no direito processual. Define Afrânio Silva Jardim o ônus da

2 FERREIRA, Aurélio Buarque de Holanda. Minidicionário da língua portuguesa. $4^{\mathrm{a}}$ ed. Rio de Janeiro: Nova Fronteira, 2001, p. 499; Academia Brasileira de Letras. Dicionário Escolar da Língua Portuguesa. $2^{\text {a }}$ ed. São Paulo: Companhia Editora Nacional, 2008, p. 923. 
prova como "a faculdade que tem a parte de demonstrar no processo a real ocorrência de um fato que alegou em seu interesse, o qual se apresenta como relevante para o julgamento da pretensão deduzida pelo autor da ação penal" ${ }^{3}$.

Com efeito, o ônus da prova equivale ao encargo de se carrear material probatório ao processo, i.e., é a incumbência que a parte possui de provar aquilo que alega. Assim, quem possui um ônus, probatório ou não, determinado no processo, tem o peso e toda a carga sobre ele, disso decorrendo consequências jurídicas.

As regras atinentes ao ônus da prova e sua distribuição são dirigidas às partes no instante instrutório e ao juiz no momento decisório, consistindo em atributo pertencente ao processo de partes, podendo-se afirmar que, onde as partes não governam a atividade probatória, e sim o juiz, não há lugar para as convenções sobre o ônus da prova ${ }^{4}$.

3 JARDIM, Afrânio S. Direito Processual Penal. 12a ed. Rio de Janeiro: Forense, 2003, p. 203. Nesse sentido é a lição de Cândido Rangel Dinamarco ao defini-lo como "o encargo, atribuído pela lei a cada uma das partes, de demonstrar a ocorrência dos fatos de seu próprio interesse para as decisões a serem proferidas no processo" (DINAMARCO, Cândido R. Instituições de Direito Processual Civil. $3^{\text {a }}$ ed. São Paulo: Malheiros, 2003, v. III, p. 71). Crítico do conceito de ônus, James Goldschmidt afirma que "a antítese do direito processual é carga processual, quer dizer, a necessidade de se prevenir um prejuízo processual, e, em último caso, de se obter uma sentença desfavorável, mediante a realização de um ato processual" (GOLDSCHMIDT, James. Teoria geral do processo. Trad. Leandro Farina. Leme: Fórum, 2006, p. 73). Essa concepção de Goldschmidt foi bem compreendida por Aury Lopes Júnior e Pablo Rodrigo Alflen da Silva ao exporem que "o processo, enquanto situação - em movimento -, dá origem a expectativas, perspectivas, chances, cargas e liberação de cargas. Do aproveitamento ou não dessas chances surgem ônus ou bônus. As expectativas de uma sentença favorável vão depender normalmente da prática com êxito de um ato processual anterior realizado pela parte interessada (liberação de cargas)" (LOPES JR., Aury; SILVA, Pablo Rodrigo Alflen da. Breves apontamentos in memoriam a James Goldschmidt e a incompreendida concepção de processo como "situação jurídica". Discursos Sediciosos: crime, direito e sociedade, Rio de Janeiro, v. 17, n. 19/20, p. 35-52, $1^{\circ}$ e $2^{\circ}$ semestres. 2012, p. 40).

4 Nessa direção anota Cândido Rangel Dinamarco que "as regras sobre o ônus da prova e sua distribuição constituem uma inerência do princípio dispositivo, e que onde se tivesse um processo puramente inquisitivo não se cogitaria do ônus probandi, nem das consequências do seu descumprimento, simplesmente porque ao juiz incumbiria a busca da verdade dos fatos e a cooperação 
Claro está, portanto, que o ônus da prova possui consequências endoprocessuais, instaurando-se e esgotando-se na própria atividade processual. Isso porque, da análise de sua definição deve se distinguir o significado de dever que, por sua vez, impõe uma relação bilateral distinta do conteúdo do ônus. ${ }^{5}$ Ao não se observar o ônus, tem-se consequência desfavorável apenas àquele que o descumpriu, enquanto que no dever ou obrigação, a consequência de seu descumprimento transpõe-se para além daquele que o fez ${ }^{6}$.

Admite-se, com Michele Taruffo, que o ônus da prova opera como um recurso para se resolver a incerteza acerca da prova dos fatos ${ }^{7}$. Dessa maneira, o ônus da prova no processo penal corresponde ao encargo que possui o autor da acusação de demonstrar todo o conteúdo de matiz penal que afirmou ter ocorrido, impondo ao acusador, público ou privado, a confirmação do crime e de sua autoria.

\subsection{O ÔNUS DA PROVA OBJETIVO E O ÔNUS DA PROVA SUBJETIVO}

Diante das consequências que passariam a advir para as partes da não observância do ônus a que lhe incumbira, passou-se a delimitar de forma estrita a direção desse ônus ao se estipular regras para a especificação do ônus de cada parte, prevendo as consequências do não cumprimento desse ônus. Descumprindo, portanto, as partes o ônus a que lhe incumbira, impunham-se regras de julgamento direcionadas ao juiz para solucionar o caso. Disso decorre o ônus da prova objetivo e o ônus da prova subjetivo.

O ônus da prova no processo penal, em sua feição objetiva, corresponde à delimitação de uma regra de julgamento conferida ao juiz para proferir sua decisão quando estiver diante da incerteza sobre os

das partes seria pelo menos dispensável e sequer haveria como sancioná-las pela omissão de provar" (DINAMARCO, Cândido R. A instrumentalidade do processo. $12^{\mathrm{a}}$ ed. São Paulo: Malheiros, 2005, p. 302).

5 LIMA, Marcellus Polastri. A Prova penal. 2. ed. Rio de Janeiro: Lumen Juris, 2003, p. 14.

6 BADARÓ, Gustavo Henrique Righi Ivahy. Ônus da prova no processo penal. São Paulo: Revista dos Tribunais, 2003, p. 177.

7 TARUFFO, Michele. A prova. São Paulo: Marcial Pons, 2014, p. 143. 
fatos postos. A necessidade de elaboração dessa(s) regra(s) se dá pelo dever que tem o juiz de julgar o caso, não obstante suas dúvidas acerca da causa ${ }^{8}$. Nesse particular, o ônus da prova tem como função permitir uma decisão sobre fatos não necessariamente provados.

Evidentemente que em caso de ausência de dúvida do julgador no momento final do processo não se fala em ônus probatório como regra de julgamento. A certeza na convicção do julgador afasta a incidência das regras de julgamento, pois, para o juiz, teria havido comportamento conforme a prova por qualquer das partes.

Bem de ver que o ônus da prova objetivo é direcionado ao julgador na fase decisória, não incumbindo às partes a necessidade de provarem o que alegam ${ }^{9}$, pois, nessa fase, as partes já teriam exercido a atividade probatória, restando a decisão final.

Diferentemente ocorre com a face subjetiva do ônus da prova, também denominado de direcionamento da atividade das partes ${ }^{10}$, que define a quem incumbe o ônus de provar determinado fato no processo, a dizer, diante dos fatos postos na causa cabe ao ônus da prova subjetivo direcionar a quem é dado o encargo sobre a prova.

A propósito do ônus da prova subjetivo, Gustavo Badarón ${ }^{11}$ elucida que "trata-se do encargo que pesa sobre as partes de buscar as fontes de

8 Elucida José Carlos Barbosa Moreira que "mesmo diante de material probatório incompleto, o órgão judicial está obrigado a julgar. Essa eventualidade gera riscos para as partes, na medida em que implica para cada uma delas a possibilidade de permanecer obscura a situação fática de cujo esclarecimento se esperava a emergência de dados capazes de influir decisivamente sobre o convencimento do juiz" (BARBOSA MOREIRA, José Carlos. Julgamento e ônus da prova. Temas de Direito Processual. $2^{\mathrm{a}}$ ed. $2^{\mathrm{a}}$ serie. São Paulo: Saraiva, 1988, p. 74-75). Também essa a orientação de: CINTRA, Antônio Carlos de Araújo. Comentários ao Código de Processo Civil. $3^{\mathrm{a}} \mathrm{ed}$. Rio de Janeiro: Forense, 2008, p. 20.

9 Nesse sentido, Gustavo Badaró expõe que "o ônus da prova objetivo prescinde de qualquer atividade das partes, identificando-se com a regra de julgamento a ser aplicada pelo juiz quando permanecer em dúvida no momento do julgamento" (BADARÓ, Gustavo H. Ônus... cit., p. 178).

10 A expressão é de: BADARÓ, Gustavo H. Ônus... cit., p. 181.

11 BADARÓ, Gustavo Henrique Righi Ivahy, op cit, p. 181. Apesar da ampla aceitação do ônus da prova subjetivo, entende Francisco Cavalcanti Pontes de Miranda que "o ônus da prova é objetivo, não subjetivo, e que às partes, 
prova e introduzi-las no processo, pelos meios de prova”. Aqui, por haver o direcionamento da atividade probatória, caberá à parte incumbida desse ônus o empenho para se desincumbir desse encargo, já que, caso não o faça, sofrerá, em regra, as consequências eventualmente danosas de seu insucesso.

Assim, bem definido o papel das partes no processo penal, a partir dessa definição, apontar-se-á o ônus de cada uma delas. Modernamente, a partir da Constituição Federal de 1988, que instituiu o modelo acusatório de partes no processo penal, outorgando ao Ministério Público a titularidade da pretensão acusatória, resta clara a regra sobre o ônus da prova no processo penal em sua feição subjetiva.

\section{O onnus da prova na disciplina do Código de Processo Penal}

A despeito da discussão doutrinária existente no Brasil sobre a existência ou não de repartição do ônus da prova, o Código de Processo Penal dispunha no artigo 156, caput, em sua redação original, que "a prova da alegação incumbirá a quem a fizer", que foi mantida nos mesmos termos pela Lei $\mathrm{n}^{\circ} 11.690 / 08$, que regula a disciplina probatória.

A leitura do mencionado dispositivo sugere que à parte elaboradora de uma alegação caberá o ônus da prova de sua comprovação. Essa é a conclusão aparentemente lógica que a redação nos indica, contudo, a literalidade do aludido dispositivo legal conduz a um impasse que revela a sua insuficiência prática a partir da seguinte indagação: se o acusador afirma que o réu matou e este assevera que não o fez, a quem compete a prova dos fatos? Se o acusador assegura que o réu agiu ilicitamente e este sustenta a licitude de sua ação, qual dos dois deve provar a ilicitude do fato ${ }^{12}$

A rigor, não há resposta precisa para essas indagações no Código.

Diante do entrevero que se aproximava, a doutrina estabeleceu critérios decisórios bem definidos e mais seguros, mormente, no ponto

como sujeitos da relação jurídica processual, hão de provar, inclusive, suas negações” (PONTES DE MIRANDA, Francisco C. Comentários ao Código de Processo Civil. $3^{\text {a }}$ ed. Rio de Janeiro: Forense, 2001, tomo IV, p. 270-271).

12 Os exemplos são de: TORNAGHI, Helio. Curso de Processo Penal. São Paulo: Saraiva, 1989, v. I, p. 307. 
relativo à distribuição desse ônus. Nessa esteira, desenvolveu-se corrente doutrinária, parcialmente mantida até hoje, que "confeccionou" a interpretação literal do artigo 156, caput, apontando caber ao acusador a prova da materialidade do fato e de sua autoria, enquanto que, caso a defesa sustentasse hipótese de excludente de ilicitude ou de culpabilidade, a esta caberia o ônus de provar sua ocorrência por ter alegado ${ }^{13}$, o que foi seguido quase à unanimidade pela jurisprudência ${ }^{14}$.

Assim, teceu-se orientação firme no sentido de que à acusação caberia o ônus da prova da materialidade do fato e de sua autoria (leia-se, tipicidade do fato), cabendo à defesa o ônus da prova de uma excludente de ilicitude ou culpabilidade, caso alegasse.

Impõe-se, assim, uma análise crítica das teses que deram sustentação a tal construção teórica, buscando-se os fundamentos utilizados pela doutrina pós-1941 para obter a conclusão informada.

A propósito, duas correntes nortearam a orientação interpretativa do artigo 156, caput, do Código de Processo Penal, porquanto necessário retroceder um passo na investigação da origem do que se tem hoje para propor nova leitura sobre o tema do ônus da prova das excludentes de ilicitude no processo penal brasileiro.

A primeira dessas correntes que orientaram a interpretação do artigo 156, caput, cronologicamente anterior, é oriunda do Direito Romano. Nesse modelo, em regra, a cada uma das partes incumbia a prova das

13 Ver por todos, na doutrina tida como clássica: MARQUES, José Frederico. Elementos de Direito Processual Penal, $2^{\mathrm{a}}$ ed. Campinas: Millennium, 2000, v. II, p. 346. Na doutrina recente: OLIVEIRA, Eugenio Pacelli de. Curso de Processo Penal. $10^{\mathrm{a}}$ ed. Rio de Janeiro: Lumen Juris, 2008, p. 288.

14 Nesse sentido, por exemplo: Supremo Tribunal Federal. Habeas Corpus $\mathrm{n}^{\mathrm{o}}$ 96.099-RS, Tribunal Pleno, Relator Ministro Ricardo Lewandowski, publicado no DJe em 05.06.2009; Superior Tribunal de Justiça. Recurso Especial no 888947, Quinta Turma, Relator Ministro Arnaldo Esteves Lima, publicado no DJE em 07.05.2007; Tribunal Regional Federal da $1^{\mathrm{a}}$ Região, em recentíssimo julgado, Apelação Criminal no 0014390-69.2003.4.01.3600, Terceira Turma, Relatora Desembargadora Federal Monica Sifuentes, publicado no DJ em 24.11.2017; Tribunal Regional Federal da $2^{\mathrm{a}}$ Região. Apelação Criminal $\mathrm{n}^{\mathrm{o}}$ 2007.500.1011946-4, Segunda Turma Especializada, Relator Desembargador Federal André Fontes, publicado no DJU em 09.12.2008; Tribunal Regional Federal da $3^{\text {a }}$ Região. Apelação Criminal no 17993, Primeira Turma, Relator Johnsom Di Salvo, publicado no DJF3 em 13.06.2008. 
alegações que fizesse ${ }^{15}$. Nicola Malatesta sistematizou esse entendimento propondo que a distribuição do ônus da prova estipulava um critério ontológico, totalmente baseado em presunções, denominando-o de princípio supremo para a solução de tal problema. Partindo de um juízo de probabilidades, ao se observar que uma coisa se verifica no maior número dos casos e sendo desconhecida naquela situação particular, deve se inclinar a crê-la verificada, prestigiando aquilo que ordinariamente acontece e não o que ocorre extraordinariamente. Asseverava, assim, que "o ordinário se presume e o extraordinário se prova" ${ }^{16}$.

Subsidiariamente ao denominado princípio supremo ontológico do ônus da prova, Malatesta, servindo-se novamente de máximas do Direito Romano, sugere a sistematização do princípio lógico, o qual informa que, "na colisão de fato positivo e negativo, quem afirma o positivo deve prová-lo, com preferência a quem afirma o negativo (probatio incumbit ei qui dificit, no qui negat)" 17 .

Nesse particular, transportou-se essa orientação para o processo penal no sentido de que as presunções invertem o ônus da prova com base em um juízo de probabilidades. Exemplificando a teoria de Malatesta, quando um determinado motorista comete um crime de lesão corporal na direção de veículo automotor, a regra é que tenha sido cometido culposamente, pois, crimes de trânsito normalmente ocorrem de forma culposa e, dessa forma, caso a acusação alegue ter havido dolo, excepcional nesses casos, deverá prová-lo. Ao contrário, quando um indivíduo mata outrem se presume que o tenha feito dolosamente, incumbindo a prova da culpa ao acusado, caso alegue ${ }^{18}$.

Eis a fonte teórica para a distribuição do ônus da prova no processo penal.

A segunda corrente de sustentação da tese aventada decorre de uma análise açodada da normativa do Código de Processo Civil de 1939

\footnotetext{
15 SANTOS, Moacyr Amaral. Primeiras linhas de Direito Processual Civil. $23^{\mathrm{a}}$ ed. São Paulo: Saraiva, 2004, p. 358.

16 MALATESTA, Nicola Framarino Del. A lógica das provas em matéria criminal. Tradução de Alexandre Correia. São Paulo: Saraiva, 1960, v. I, p. 137.

17 MALATESTA, Nicola Framarino Del. A lógica...cit., p. 138.

18 TORNAGHI, Helio. Curso...cit., p. 307.
} 
e, posteriormente, do Código de Processo Civil de 1973, servindo-se da omissão do legislador processual penal para concluir que, ao autor caberia a prova do fato típico objeto da acusação e ao réu incumbiria o ônus de provar as alegações referentes aos fatos excludentes da ilicitude ou da culpabilidade ${ }^{19}$.

Catalogaram-se, assim, equivocadamente, as alegações defensivas, sobretudo, as excludentes de ilicitude e culpabilidade como espécies de fatos impeditivos, modificativos e extintivos ${ }^{20}$. Definitivamente não o são, conforme se verá adiante.

\section{Retroceder PARA COMPREENDER: ANÁLISE DAS ORIGENS DA REGRA DO ÔNUS DA PROVA NO PROCESSO PENAL A PARTIR DA NORMATIVA PROCESSUAL CIVIL}

A primeira questão merecedora de análise é a pretensão de se equiparar as alegações defensivas, especialmente as excludentes de ilicitude, a fatos impeditivos, modificativos ou extintivos do direito do autor, utilizando-se, por analogia, o artigo 209, $\S \S 1^{\circ}, 2^{\circ}$, do Código de Processo Civil de 1939 e o artigo 333, I, II, do Código de Processo Civil de 1973, o qual tem influenciado significativamente a jurisprudência brasileira.

Primeiramente porque, mesmo no âmbito da doutrina processual civil, não há definição precisa dos fatos impeditivos, modificativos e extintivos do direito do autor a serem alegados e provados pelo réu.

19 Relevante se mostra a análise de trecho do julgado do Supremo Tribunal Federal acima mencionado ( $\mathrm{HC} \mathrm{n}^{\circ}$ 96.099-RS...cit), no qual fica claro esse entendimento: “(...) Incumbe à acusação demonstrar os fatos criminosos imputados ao acusado, cabendo a este, contudo, caso o alegue, provar eventual causa excludente de tipicidade, antijuricidade, culpabilidade ou extintiva de punibilidade. Como se sabe, a lei processual civil e penal outorga à parte o direito e, ao mesmo tempo, a obrigação de demonstrar fato que alega em seu interesse. Não seria razoável exigir da vítima ou do Estado-acusador comprovar o potencial lesivo da arma, quando o seu emprego tiver sido evidenciado por outros meios de prova, mormente quando esta desaparece por ação do próprio acusado, como usualmente acontece após a prática de delitos dessa natureza (...)"

20 TORNAGHI, Helio. Curso...cit., p. 308-309; NUCCI, Guilherme de Souza. O valor da confissão como meio de prova no Processo Penal. $2^{\mathrm{a}}$ ed. São Paulo: Revista dos Tribunais, 1999, p. 70. 
Para que se pretendesse transpor a mencionada regra de distribuição do ônus para o campo processual penal seria imprescindível delimitar a matéria na seara própria da dogmática processual civil ${ }^{21}$, caso contrário, estar-se-ia forçando em demasia uma interpretação. Classicamente, Giuseppe Chiovenda ${ }^{22}$ define os fatos constitutivos do direito do autor "como os fatos que normalmente produzem determinados efeitos jurídicos”.

Entende-se o fato constitutivo do direito do autor como o fato que origina esse direito, fazendo com que surja para ele a prerrogativa de estar em juízo pretendendo a satisfação do direito alegado. Dessa maneira, segundo a lógica do artigo 333, I, do Código de Processo Civil de 1973, incumbirá ao próprio autor a prova do alegado fato constitutivo desse direito, pois, não logrando tal demonstração, não terá se desincumbido de seu ônus e sofrerá as consequências com a improcedência do pleito ${ }^{23}$. A propósito da regra do ônus da prova do fato constitutivo, a questão se encontra bem definida.

Não se diga o mesmo sobre a regra do ônus da prova dos fatos impeditivos, modificativos e extintivos do direito do autor, sobre os quais resultam sérias dúvidas, notadamente pela divergência doutrinária a respeito da definição desses fatos jurídicos.

De forma genérica, os fatos impeditivos, modificativos e extintivos do direito do autor são aqueles que, na sua forma, atuam diretamente na constituição daquele alegado direito, possuindo o condão de impedir sua formação, modificá-lo ou mesmo extingui-lo. Essa generalidade fica clara no escólio de Enrico Tullio Liebman, ao sugerir que "fatos modificativos

${ }^{21}$ Leciona José Frederico Marques que "na aplicação das regras expostas, as dificuldades residem em qualificar, nos casos concretos, os fatos jurídicos, ou como extintivos ou como constitutivos". (MARQUES, José F. Manual de Direito Processual Civil, v. II, 2. ed. Campinas: Millennium, 2000. p. 269).

22 CHIOVENDA, Giuseppe. Instituições de Direito Processual Civil. Tradução da 2. ed. Italiana de J. Guimarães Menegale. São Paulo: Saraiva, 1969, v. II, p. 382. Semelhante idéia é sustentada por Vicente Greco Filho, para quem "os fatos constitutivos são aqueles que, se provados, levam à consequência jurídica pretendida pelo autor" (GRECO FILHO, Vicente G. Direito Processual Civil Brasileiro, v. II, $16^{\circ}$ ed. São Paulo: Saraiva, 2003. p. 191).

23 Nesse sentido: SANTOS, Moacyr Amaral. Primeiras linhas...cit., p. 357, e SILVA, Ovídio Baptista da. Curso de Processo Civil. $5^{\mathrm{a}}$ ed. São Paulo: Revista dos Tribunais, 2000, p. 344. 
são os que modificam a capacidade de produzir o efeito jurídico dos fatos constitutivos; fatos extintivos seriam os que produzem a extinção do efeito causado pelo fato constitutivo; e fatos impeditivos aqueles que, quando acompanham os fatos constitutivos, valem como impedimento à produção do seu efeito normal" ${ }^{24}$.

Não havendo, portanto, precisão conceitual dos fatos impeditivos, modificativos ou extintivos da constituição do direito do autor, limita-se a doutrina, no mais das vezes, a exemplificá-los para empreender sua aplicação ${ }^{25}$.

Nem mesmo a doutrina processual civil pós-2015, com o novo Código, que repetiu a regra no seu artigo 373, foi mais esclarecedora nessa definição. Assim, para Daniel Neves, "por fato impeditivo entende-se aquele de conteúdo negativo, demonstrativo da ausência de algum dos requisitos genéricos de validade do ato jurídico como, por exemplo, a alegação de que o contratante era absolutamente incapaz quando celebrou o contrato. Fato modificativo é aquele que altera apenas parcialmente o fato constitutivo, podendo ser tal alteração subjetiva, ou seja, referente aos sujeitos da relação jurídica (como ocorre na cessão de crédito) ou objetiva, ou seja, referente ao conteúdo da relação jurídica (como ocorre, por exemplo, na compensação parcial). Fato extintivo é o que faz cessar a relação jurídica original, como a compensação numa ação de cobrança"²6.

24 LIEBMAN, Enrico T. Manual de Processo Civil. 2. ed. Tradução de Cândido R. Dinamarco. Rio de Janeiro: Forense, 1985, p. 165. Também assim, v. GRECO FILHO, Vicente. Direito...cit., p. 191.

25 Moacyr Amaral Santos exemplifica como "fato impeditivo o réu reconhecer que negociou a venda, mas alegar que não tinha capacidade de obrigar-se; fato extintivo, reconhecer o réu que contraiu a dívida, mas que já pagou, e fato modificativo, reconhecer o réu que contraiu a dívida, mas afirmar que, por acordo, ela foi parcelada, sendo no momento tão-somente devida em parte" (SANTOS, Moacyr A. Primeiras linhas...cit., p. 195). Também exemplificando, Luiz Guilherme Marinoni e Sérgio Cruz Arenhart assinalam como fato extintivo o pagamento de uma dívida (numa ação de cobrança); como fato modificativo o parcelamento dessa dívida; e como fato impeditivo a exceção de contrato não cumprido, ou seja, que o autor não cumpriu sua obrigação decorrente do contrato (MARINONI, Luiz Guilherme; ARENHART, Sérgio Cruz. Curso de Processo Civil: Processo de Conhecimento. $7^{\mathrm{a}}$ ed. São Paulo: RT, 2008, vol. II, p. 135).

26 NEVES, Daniel. Novo código de processo civil comentado. Salvador: Juspodivm, 2016, p. 657. No mesmo sentido: "Afirma-se que os fatos constitutivos são aqueles que dão vida a um efeito jurídico e à expectativa de um bem por 
Ademais, outro desdobramento necessário dessa temática é a linha fronteiriça entre a negação ou contraprova do direito constitutivo e os fatos impeditivos, modificativos e extintivos, que é mínima e, por vezes, confundem-se, remetendo toda a problemática para o ônus da prova ${ }^{27}$.

Assim, caso o réu, ao se defender, tire o foco da matéria embutida no direito constitutivo do autor e se dirija a fatos externos desse direito, como os fatos impeditivos, modificativos ou extintivos, se incumbirá de prová-los por ter trazido à discussão fato não alegado pelo autor, mas que atinge diretamente a constituição do fato.

No entanto, cumpre definir até que ponto a contraprova ou a negação do direito do autor pelo réu se enquadraria como fato impeditivo, modificativo ou extintivo desse direito, pois, atuando o réu nos estreitos limites do fato constitutivo o ônus da prova permanece sendo do autor. Por exemplo, afirmar o réu que a dívida já se encontra quitada seria fato extintivo do direito do autor ou a própria contraprova do direito constitutivo? Está o réu alegando fato extintivo ou contestando o próprio direito constitutivo com a contraprova dos fatos alegados pelo autor, e, assim, atuando dentro do limite do direito constitutivo?

As respostas a serem dadas acarretarão consequências diretas na repartição do ônus da prova ${ }^{28}$, pois, ao se enquadrar a contestação do

parte de alguém. Na mesma linha, os fatos extintivos são aqueles que fazem cessar um efeito jurídico e a consequente expectativa de um bem. Os fatos impeditivos constituem a falta de uma das circunstâncias para que concorra um fato constitutivo. Já os fatos modificativos são aqueles que pressupõem a válida constituição do direito, porém, tendem a alterá-lo" (MARINONI, Luiz Guilherme; ARENHART, Sérgio Cruz; MITIDIERO, Daniel. Novo código de processo civil comentado. $2^{\mathrm{a}}$ ed. São Paulo: RT, 2016, p. 449).

27 Nesse particular destaca Giuseppe Chiovendaser "muitas vezes difícil estabelecer se um fato é um fato jurídico autônomo, ou seja, fundamento de um meio autônomo de defesa, sujeito aos ônus da prova, ou se é simples negação do fato afirmado pelo adversário, e, pois, sujeito a prova apenas quando o adversário tiver provado o fato como ele o afirma" (CHIOVENDA, Giuseppe. Instituições...cit., p. 380).

28 Nessa linha afirma Cassio Scarpinella que "a depender do conteúdo da contestação, o próprio procedimento a ser observado pelo magistrado a partir da prática daquele ato processual poderá se alterar como, também, a atribuição do 'ônus da prova', isto é, a verificação sobre quem, autor ou réu, terá de provar tais e quais fatos" (BUENO, Cassio Scarpinella. Curso sistematizado de direito processual civil. São Paulo: Saraiva, 2007. v. I, p. 461). 
fato como contraprova do direito constitutivo caberá ao autor prová-lo, enquanto que, se for definido como fato impeditivo, modificativo ou extintivo do direito do autor, transfere-se toda a carga da prova ao réu, sofrendo este as consequências da ausência de prova suficiente.

Nesse particular, Luiz Guilherme Marinoni e Sérgio Cruz Arenhart estabelecem que "há contraprova quando o réu contesta o fato constitutivo e requer prova em relação a ele. A contraprova não é apenas a que objetiva invalidar formalmente a prova do fato constitutivo, como a que visa demonstrar a falsidade do documento que aponta para o fato constitutivo. A contraprova diz respeito ao próprio fato constitutivo e não apenas à sua prova”. ${ }^{29}$ De sua vez, Cândido Rangel Dinamarco leciona que “a afirmação contrária, feita pelo réu em contestação, poderá consistir simplesmente em negar o fato, sem propor outra versão; ou em propor outra versão dos fatos, diferente daquela sustentada pelo autor; ou ainda em desenvolver argumentos lógicos destinados a demonstrar que os fatos não poderiam, ou dificilmente poderiam ter acontecido conforme descritos na petição inicial. Substancialmente, em qualquer destas hipóteses o réu está a negar o fato constitutivo alegado pelo autor, e daí o ônus probatório lançado sobre este (art. 333, I)" ${ }^{30}$.

Finalmente, Giuseppe Chiovenda sustenta que "a simples negação dos fatos afirmados pela outra parte não impõe qualquer ônus da prova. Mesmo em caso de negação indireta, isto é, de afirmação de um fato incompatível com o alegado pelo autor, não tem o réu, para o momento, de provar o fato que ele alega; porquanto, se bem afirme um fato autônomo, o faz para negar o fato constitutivo do direito do autor, e não apenas para opor-se a seus efeitos jurídicos". ${ }^{31}$

Com isso, a mera reação à pretensão não conduz automaticamente ao seu enquadramento como fato impeditivo, modificativo ou extintivo do direito do autor. Limitando-se o réu a negar o fato constitutivo ou afirmar que tenha ocorrido de forma diversa do alegado pelo autor haverá a contraprova daquele fato, mantendo-se, a rigor, o ônus da prova do

29 MARINONI, Luiz Guilherme; ARENHART, Sérgio Cruz. Curso...cit., p. 269.

30 DINAMARCO, Cândido Rangel. Instituições...cit., p. 464. Também nessa linha: LIEBMAN, Enrico Tullio. Manual...cit., p. 168.

31 CHIOVENDA, Giuseppe. Instituições...cit., p. 380. 
autor. Sustenta-se, então, que, quando se estiver trabalhando no âmbito dos fatos alegados pelo autor e discutindo em torno desses fatos, haverá contraprova. Vê-se, portanto, que o foco da discussão está cingido aos contornos do contexto fático colacionado pelo autor ${ }^{32}$.

Diferentemente ocorre quando o réu, ao contestar o fato constitutivo, afirma algo capaz de impedir que esse fato produza os seus efeitos ou fatos que impliquem a modificação ou a extinção do direito. Nesse caso, não há apenas contraprova pela simples razão de que não houve apenas contestação ao fato constitutivo ${ }^{33}$. A rigor, há fuga do contexto fático inicial, adentrando-se fatos outros com plena capacidade jurídica para exercer sobre o fato constitutivo impedimento, extinção ou modificação.

A despeito de toda a sorte de discussão existente sobre esse ponto específico da doutrina processual civil, ressalte-se a inadequação da aplicação da regra inserta no Código de Processo Civil para o ônus da prova no processo penal, pois, a distinção entre fato constitutivo e fatos impeditivos, modificativos e extintivos no âmbito processual civil em nada se assemelha ao ônus da acusação em provar a tipicidade e autoria do fato e à defesa o ônus de provar as causas excludentes de ilicitude. Trata-se de uma equiparação indevida e perigosa entre tipicidade e fato constitutivo do direito do autor e entre excludentes de ilicitude e/ou culpabilidade e fatos impeditivos, modificativos e extintivos desse direito.

Dessa maneira, ainda que se insista na transposição da disciplina processual civil para o processo penal, as causas excludentes de ilicitude devem ser incluídas plenamente como a contraprova do próprio fato constitutivo do direito do autor, e não como um fato extintivo ou impeditivo desse direito. Isso por uma razão básica, a saber, sustentar uma excludente

32 Assim se posiciona Humberto Theodoro Junior "para aplicar-se corretamente o art. 333, II, deve-se levar em conta que não é defesa indireta aquela em que o réu nega veracidade à versão do autor e indica outra versão para o fato invocado na petição inicial. Se o autor, por exemplo, afirma que seu veículo foi abalroado pelo do réu, e este contesta afirmando ter sido o veículo do autor que abalroou o seu, não se pode dizer que o contestante teria invocado fato extintivo ou modificativo do direito do autor. O promovente da ação continua com o ônus de provar que seu automóvel foi abalroado, para lograr êxito na ação intentada" (THEODORO JUNIOR, Humberto. Curso de direito processual civil. v. I, $44^{\mathrm{a}}$ ed. Rio de Janeiro: Forense, 2006, p. 463).

33 MARINONI, Luiz Guilherme; e ARENHART, Sérgio Cruz. Curso...cit., p. 270. 
de ilicitude significa "trabalhar" dentro do âmbito fático trazido pelo autor, resumindo-se o réu a contrariar esses fatos ao afirmar que teriam ocorrido não da forma confeccionada pelo autor, mas de forma distinta. É a própria contestação fática produzida pelo réu sobre os fatos imputados.

A advertência que se faz repousa no fato de querer se aplicar, no direito processual penal, questão inerente ao direito processual civil que sequer foi suficientemente definida nessa seara. Ademais, ao se utilizar no processo penal a regra cunhada para o processo civil, deixou de se atentar que no processo civil há repartição do ônus da prova entre as partes, com a disposição dessa distribuição, enquanto no processo penal inexiste tal repartição entre as partes, suportando a parte acusadora o ônus da prova integralmente.

Por último, ainda que possível fosse transpor a disciplina processual civil para o processo penal, estar-se-ia incorrendo em flagrante equívoco ao tentar equiparar uma justificativa penal laborada pelo réu, $v . g$, uma legítima defesa ou estado de necessidade, a um fato impeditivo, modificativo ou extintivo do direito do autor, renegando-se, pois, o próprio conceito de crime e, por conseguinte, toda a evolução da teoria do delito.

Para tanto, merece análise, dentro do campo devido, i.e, da teoria do delito, o conceito de crime e a relação entre tipicidade e ilicitude para se confirmar ou não a equiparação dos fatos constitutivos com a prova da autoria e materialidade e a equiparação dos fatos impeditivos, modificativos ou extintivos com as causas excludentes de ilicitude.

\section{A RELAÇÃo ENTRE TIPICIDADE E ILICITUDE NA TEORIA DO DELITO}

Antes de se equiparar o fato constitutivo do direito do autor e tipicidade penal, bem como uma aproximação dos fatos impeditivos, modificativos e extintivos do direito do autor com a alegação de uma excludente de ilicitude pelo acusado, deve-se analisar a própria estrutura teórica da tipicidade, ilicitude e culpabilidade que, dada sua peculiaridade, escapa à discussão no âmbito cível.

A transposição da disciplina civil para a sistemática processual penal revela desconhecimento da teoria do delito, campo próprio para o estudo da tipicidade, ilicitude e culpabilidade. Em outros termos, a 
"arquitetura" do conceito de crime é exclusiva da dogmática jurídico-penal e nela deve se findar. Com efeito, deve-se analisar as diversas teorias existentes acerca da relação entre tipicidade e ilicitude.

A tipicidade, conforme aduz Cezar Bitencourt, "é a conformidade do fato praticado pelo agente com a moldura abstratamente descrita na lei penal" ${ }^{4}$. Em síntese, é a própria adequação da conduta humana a determinado tipo penal. A sua vez, a ilicitude é um conceito geral do ordenamento jurídico, compreendendo-se como a contrariedade à norma. Juarez Cirino dos Santos define a ilicitude em direito penal como "uma contradição entre a ação humana (realizada ou omitida) e o ordenamento jurídico no conjunto de suas proibições e permissões"35.

Acerca das diversas teorias que se dedicaram ao estudo da relação entre tipicidade e ilicitude, inicie-se com a denominada teoria do tipo independente ou do tipo avalorado, responsável pelos primeiros estudos sobre a relação existente entre tipicidade e antijuridicidade. Capitaneando essa teoria, defensora da total independência entre tipicidade e antijuridicidade, Beling afirmava que o tipo possui característica puramente descritiva, analisando sempre essas duas categorias do delito de forma isolada. Assim, nessa concepção, a tipicidade era um elemento essencial do delito que se diferenciava nitidamente da antijuridicidade ${ }^{36}$. Ao resumir essa teoria, Miguel Polaino Navarrete afirma que "o tipo seria um elemento delimitador da matéria delitiva que contém somente as características do delito externo-objetivamente constatáveis, sendo dele excluída toda referência psíquica, que só encontrará adequada ubiquação no âmbito da culpabilidade" 37 .

A tipicidade, portanto, atenderia a uma função meramente descritiva, objetiva e estanque, restando à ilicitude a análise acerca da conduta

${ }^{34}$ BITENCOURT, Cezar. Tratado de Direito Penal: parte geral. $9^{a}$ ed. São Paulo: Saraiva, 2004, v. I. p. 247.

35 SANTOS, Juarez Cirino dos. Direito penal: parte geral. $2^{\text {a }}$ ed. Curitiba: ICPC; Lumen juris, 2007, p. 219.

36 CEREZO MIR, José. Derecho penal: parte general: lecciones 26-40. 2. ed. Madrid: Universidad Nacional de Educación a Distancia, 2000, p. 458.

37 NAVARRETE, Miguel Polaino. Derecho penal: parte general. Barcelona: Bosch, 2000, v. I, tomo II, p. 404-408. 
praticada de modo a se concluir por seu enquadramento legal ou não ${ }^{38}$. Dessa forma, atenderiam tipicidade e ilicitude a funções distintas.

Na esteira da preconizada teoria, atualmente superada, o entendimento do ônus da prova no processo penal nos moldes do artigo 373, do Código de Processo Civil, seria coerente, pois, ao separar a tipicidade da ilicitude tornando-as autônomas, pode-se classificá-las também de forma autônoma. Isso porque, quanto mais separadas estivessem mais fácil se tornava a configuração da ilicitude como algo extintivo ou impeditivo da tipicidade, a dizer, da constituição do direito do autor ${ }^{39}$.

$\mathrm{Na}$ esteira evolutiva das teorias do delito, especialmente sobre a relação entre tipicidade e ilicitude, deve-se a Mayer o início da aproximação entre essas duas categorias ${ }^{40}$, consistindo a tipicidade no principal indício ou fator de conhecimento da ilicitude, sendo esta relação similar à existente entre a fumaça e o fogo ${ }^{41}$, conquanto distintas. Essa teoria indiciária vislumbrava, portanto, a tipicidade como a ratio cognoscendi da ilicitude, ou seja, um indício desta ${ }^{42}$.

Aproximando tipicidade e ilicitude, Edmund Mezger desenvolve a Teoria da tipicidade como a ratio essendi da ilicitude. Avançando na teoria de Mayer, compreendeu Mezger que "o tipo penal é fundamento real e de validade (ratio essendi) da ilicitude, ressalvando-se que a ação não seja justificada em virtude de uma causa especial de exclusão do injusto. Se isso ocorre, a ação não é antijurídica, apesar de sua tipicidade" ${ }^{* 3}$.

Vê-se, assim, na teoria da ratio essendi a ilicitude como a própria razão de ser da tipicidade, sua essência. Nessa altura, a evolução da

38 REALE JUNIOR, Miguel. Antijuridicidade concreta. São Paulo: José Bushatsky, 1974 , p. 35.

39 A teoria do tipo independente possui o grande mérito de ter sido a pioneira a se dedicar com profundidade ao tema da tipicidade e sua relação com a antijuridicidade e, a despeito de não atender aos anseios contemporâneos da teoria do delito, muito contribuiu para a evolução do tema.

REALE JUNIOR, Miguel. Antijuridicidade...cit., p. 35.

CEREZO MIR, José. Derecho penal...cit., p. 458.

Conquanto conservadora, essa teoria promoveu grande avanço para a moderna teoria do fato punível ao constatar a existência de uma relação existente entre tipicidade e antijuridicidade, ligando-as por uma relação lógica.

MEZGER, Edmund. Tratado de derecho penal. $2^{\text {a }}$ ed. Madrid: RDP, 1955, t. I, p. 376. 
teoria do delito encerrou a distância, separação e independência antes existentes entre tipicidade e ilicitude.

A completa fusão entre tipicidade e ilicitude se dá através da denominada Teoria dos elementos negativos do tipo, que apregoa uma identidade entre essas duas categorias jurídicas do delito. Foi concebida originalmente por Merkel e Baumgarten, tendo sido cultuada modernamente por Hinrichsen, Schröder, Kaufmann e Engish ${ }^{44}$.

Segundo informa a teoria dos elementos negativos de tipo, no bojo da tipicidade se encontra também a ilicitude, ou seja, a ausência de uma causa de justificação. Em sua face moderna, essa teoria assinala que pertencem ao tipo não apenas as circunstâncias que fundamentam o injusto de uma figura delitiva, mas também, como elementos negativos, a ausência das circunstâncias que servem de base às causas de justificação ${ }^{45}$.

De acordo com essa orientação, a relação entre tipicidade e ilicitude é inseparável, somente existindo uma se presente a outra. Funciona como uma espécie de esquema "tudo ou nada". O afastamento de qualquer delas importa o consequente afastamento da restante. Assim, se presente uma causa de justificação, a conduta não é apenas lícita, mas, atípica. Com isso, no caso de um crime de homicídio, a leitura do tipo é a seguinte: "Matar alguém sem a concorrência de legítima defesa (ou outra qualquer excludente de ilicitude)" ${ }^{46}$.

A base da teoria dos elementos negativos do tipo decorre da sustentada ausência de diferença substancial entre os elementos positivos que fundamentam o injusto de uma conduta delitiva e os elementos negativos que servem como causa de justificação, estando estas últimas na parte geral do código por razões de técnica legislativa, podendo ser incluídas nas próprias figuras delitivas da parte especial ${ }^{47}$.

CEREZO MIR, José. Derecho penal...cit, p. 462. Naturalmente, a teoria dos elementos negativos do tipo não passou imune às críticas da doutrina. Criticando a teoria Eugenio Raul Zaffaroni aduz que "a teoria dos elementos negativos do tipo retroage a teoria do delito aos tempos anteriores à introdução do conceito de tipo penal” (ZAFFARONI, Eugenio Raul. Manual de Derecho Penal. México: Cardenas, 1988, p. 402). Na mesma linha crítica: José Cerezo Mir. Derecho penal...cit, p. 472. 
A par da sucinta exposição da evolução da relação entre tipicidade e ilicitude, permitindo a compreensão desses institutos, o que se pretende demonstrar é a total inviabilidade de equiparação da ilicitude a fato impeditivo ou extintivo do direito, de modo a que se atribua ao réu a prova dessa excludente ${ }^{48}$. Conquanto os fatos impeditivos, extintivos ou modificativos do direito do autor sejam diversos do seu direito constitutivo e, portanto, fora deles, a tipicidade, a ilicitude e a culpabilidade, ao contrário, a um só tempo consistem no próprio direito do autor, como demonstrado pela análise das teorias do delito

Manifestamente incongruente, portanto, a concepção da tipicidade como fato constitutivo, e da ilicitude como fato impeditivo ou extintivo do direito de punir. A aproximação desses institutos significa retroceder ao começo do estudo da tipicidade e da ilicitude para torná-las categorias opostas, ignorando-se por completo conceitos básicos da teoria do delito ao não se conceber um crime como fato típico, ilícito e culpável, inseparável em sua natureza ${ }^{49}$.

É sabido que o delito é algo inteiramente unitário e não se divide em três partes autônomas. Sua eventual divisão atende tão somente a critérios dogmáticos objetivando uma melhor análise estrutural ${ }^{50}$.

Não há como concordar com a orientação que sustenta o intercâmbio acrítico do conteúdo do artigo 373, do Código de Processo Civil para a realidade processual penal, buscando conferir o ônus da prova do fato constitutivo do direito (tipicidade e autoria) ao autor e a prova dos fatos impeditivos, extintivos ou modificativos (que seriam, segundo a decantada construção, as excludentes de ilicitude ou culpabilidade) ao réu que os alegar.

48 Nesse sentido, v. BADARÓ, Gustavo Henrique Righi Ivahy. Ônus...cit., p. 315.

49 Nesse sentido, Eugenio Raul Zaffaroni critica a teoria do tipo independente ou avalorado justamente por entender inadmissível afirmar que a tipicidade não nos diz absolutamente nada a respeito da antijuridicidade (ZAFFARONI, Eugenio R. Manual...cit., p. 402).

50 JARDIM, Afrânio Silva. Direito...cit., p. 207. Cezar Roberto Bitencourt assevera que "a divisão do delito em três aspectos, para fins de avaliação e valoração, facilita e racionaliza a aplicação do direito, garantindo a segurança contra as arbitrariedades e as contradições que poderiam ocorrer" (BITENCOURT, Cezar Roberto. Tratado... cit., p. 286). 
Definitivamente, o que o direito processual civil chama de fato constitutivo do direito do autor o direito penal chama de crime, a dizer, um fato típico, ilícito e culpável, ou seja, um fenômeno único ${ }^{51}$. Não se pode, portanto, desmembrar o conceito analítico de crime para o fim de repartir o ônus da prova entre as partes, sendo de todo equivocado ler o conceito de crime com as lentes do art. 373, I, II, do Código de Processo Civil, razão pela qual se afasta completamente essa pretendida analogia.

\section{O ÔNUS DA PROVA DAS EXCLUDENTES DE ILICITUDE NO PROCESSO PENAL}

Superada a discussão concernente à regra do ônus da prova prevista na lei processual civil, cumpre abordar o tema central do presente trabalho, a saber, a regra de julgamento das excludentes de ilicitude no direito processual penal.

A fonte normativa para o desenvolvimento da temática é o disposto no artigo 156, caput, do Código de Processo Penal, que, numa redação parcimoniosa, levou e continua levando sérias dúvidas à orientação do julgador no momento decisório.

Conforme exposto, a leitura do mencionado artigo 156, caput, do CPP, conjugada com a disposição do artigo 333, I, II, do Código de Processo Civil de 1973, conduziu ao entendimento de que o ônus da prova das excludentes de ilicitude incumbe sempre à defesa quando as alegar ${ }^{52}$. Todavia, tal corrente peca por analisar a questão equivocadamente.

51 Nesse mesmo sentido, Frederico Gomes de Almeida Horta afirma que "não se pode admitir que o ônus probatório da acusação se limite à demonstração da autoria e materialidade do fato típico pela simples razão de que a mera tipicidade da conduta atribuída ao acusado não faz dela um fato constitutivo do poder estatal de puni-lo, deduzido em juízo por meio da ação pena. Com efeito, o fato constitutivo do ius puniendi é o crime punível, que não se verifica apenas pela tipicidade, mas também, necessariamente pela ilicitude, culpabilidade e punibilidade da conduta do acusado" (HORTA, Frederico Gomes de Almeida. Do ônus da prova dos elementos de valoração global do fato: análise crítica de precedente do Superior Tribunal de Justiça (STJ, HC 194.225). Revista Brasileira de Ciências Criminais, São Paulo, v. 21, n. 104, p. 173-202, set./out. 2013, p. 197).

52 Nesse sentido: PEDROSO, Fernando de Almeida. A Prova Penal. $2^{\text {a }}$ ed. São Paulo: RT, 2005, p. 26, e NUCCI, Guilherme de Souza. Provas no processo penal. São Paulo: RT, 2009, p. 23. 
A um só tempo, distorce-se o artigo 333, I, II, do CPC/73 e, consequentemente o artigo 373, do CPC/2015, e vislumbra-se parcialmente o artigo 156, caput, do Diploma Processual Penal. Isso porque a correta complementação da regra do art. 156, caput, do Código de Processo Penal deve ser feita com os artigos 41 e 386, VI, VII, CPP 53 , este último com redação dada pela Lei 11.690/08. Desse modo, ter-se-ia no artigo 156, caput, a seguinte redação de lege ferenda: "A prova da alegação incumbirá a quem a fizer, cabendo à acusação a prova do fato criminoso com todas as suas circunstâncias, conforme exposto na denúncia, impondo-se a absolvição caso não exista prova suficiente para a condenação ou se houver dúvida quanto à existência de causa excludente da ilicitude" ${ }^{54}$.

Por meio da análise sistemática do ordenamento processual penal, ao se dispor a necessidade de exposição do fato criminoso com todas as suas circunstâncias, conforme consta no artigo 41, do Código de Processo penal, devem estas ser compreendidas como as fáticas e as jurídicas, i.e, todos os fatos envoltos, bem como todas as circunstâncias jurídicas daquele fato criminoso, quais sejam, sua tipicidade, ilicitude e culpabilidade ${ }^{55}$.

O ônus da acusação de provar a ausência das excludentes de ilicitude, dessa maneira, restaria evidente já no momento do oferecimento da denúncia e o acompanharia durante todo o processo.

Já foi aqui colocado que o crime é unitário, só havendo sua repartição teórica por motivos didáticos. Em consequência, todo o ônus da prova do fato criminoso é do acusador e, sendo o fato criminoso ação

53 Essa a lição de: JARDIM, Afrânio Silva. Direito... cit., p. 208.

54 Veja-se, a propósito, proposta de Maria Lucia Karam para uma adequada denúncia: "O réu teria - supondo-se que se trate de furto - subtraído, para si, uma determinada coisa alheia móvel, de valor economicamente considerável, assim afetando o patrimônio do ofendido, em circunstâncias em que tal conduta não era permitida e podendo, dada a normalidade das circunstâncias, atuar como determinava o comando legal e, assim, ser responsabilizado pela prática daquela infração penal, a normalidade das circunstâncias indicando, ainda, a necessidade de imposição da pena” (KARAM, Maria Lucia. Sobre o ônus da prova na ação penal condenatória. Revista Brasileira de Ciências Criminais, São Paulo, v. 9, n. 35, jul./set. 2001, p. 65).

55 JARDIM, Afrânio Silva. Direito...cit., p. 208, faz expressa referência à necessidade de o acusador provar circunstâncias jurídicas. 
típica, ilícita e culpável, assevera-se que ao acusador incumbe o ônus de demonstrar, além do fato típico, a ilicitude e culpabilidade ${ }^{56}$. Pensar o contrário significaria atribuir o ônus da prova de demonstrar a excludente de ilicitude ao acusado, invertendo-0 $0^{57}$.

A pretensão de utilização da disciplina processual civil acarreta inversão desse ônus, pois, a ilicitude do fato constitui a própria pretensão punitiva estatal, não se enquadrando, em hipótese alguma, na categoria de fato impeditivo, modificativo ou extintivo. Fosse possível a utilização da regra de repartição do ônus da prova do Código de Processo Civil no processo penal, dever-se-ia incluir a ilicitude e culpabilidade, somadas à tipicidade, no bojo do inciso I do artigo 373, do CPC, caracterizando o fato constitutivo da pretensão acusatória do Estado ${ }^{58}$.

Não bastasse tudo isso, com a Constituição Federal de 1988, o ônus da prova no processo penal ganhou maior relevo e menor dúvida com o estabelecimento da presunção de inocência em seu artigo $5^{\circ}$, LVII, acrescentando um ingrediente a mais na atividade do acusador diante da impossibilidade de se antever a culpa do imputado sem que a decisão penal esteja definitivamente afirmada com trânsito em julgado.

Isso porque a presunção de inocência, em sua acepção probatória, estabelece para o acusador todo o ônus de provar o teor da acusação.

56 Assim parece a Gustavo Badaró ao asseverar que "o ônus da prova incumbe inteiramente ao Ministério Público, que deverá provar a presença de todos os elementos de fato dos quais decorre a pretensão punitiva e a inexistência de todos os elementos que obstem o surgimento da pretensão punitiva" (BADARÓ, Gustavo H. Ônus...cit., p. 319).

57 Nesse sentido: BADARÓ, Gustavo H. Ônus...cit., p. 310. Aury Lopes Jr. afirma que "erro crasso pode ser percebido quase que diariamente nos foros brasileiros: sentenças e acórdãos fazendo uma absurda distribuição de cargas no processo penal, tratando a questão da mesma forma que no processo civil. Não raras são as sentenças condenatórias fundamentadas na 'falta de provas da tese defensiva', como se o réu tivesse que provar sua versão de negativa de autoria ou da presença de uma excludente" (LOPES JR., Aury. Réu não deve ser obrigado a provar causa de exclusão da ilicitude. Revista Magister de Direito Penal e Processual Penal, Porto Alegre, v. 12, n. 67, p. 43-47, ago./set. 2015, p. 44,).

58 Essa a orientação de Gustavo Badaró: “antijuridicidade não é um fato impeditivo do direito de punir, mas sim parte integrante do fato constitutivo deste direito, juntamente com a tipicidade e a culpabilidade" (BADARÓ, Gustavo H. Ônus...cit., p. 318). 
Qualquer falha ou insucesso no cumprimento desse ônus deve pesar em desfavor da acusação, jamais sobre o réu.

Michele Taruffo $\mathrm{o}^{59}$, destacando como característica distintiva do processo penal a existência da presunção de inocência, adverte que "esta presunção introduz um desequilíbrio estrutural na posição das partes a respeito da prova no processo penal, dado que a posição de uma parte (imputado) é favorecida sistematicamente, enquanto que a outra (acusação) é sistematicamente desfavorecida pela distribuição de ônus probatórios”. Acrescente-se que o desequilíbrio proporcionado pela presunção de inocência em favor do réu tem por escopo justamente (re)equilibrar a relação processual penal primitivamente danosa e prejudicial ao réu, o qual se encontra em franco desequilíbrio frente ao sistema punitivo estatal.

Nesse ponto, com a presunção de inocência, exigir que o acusado inocente prove a licitude de sua conduta, a dizer, que agira encoberto por uma causa excludente da antijuridicidade, desfigura aquela garantia constitucionalmente assegurada ${ }^{60}$. Assim, com a existência da presunção de inocência em favor do penalmente perseguido, ratifica-se a obrigatoriedade de o acusador comprovar todos os elementos pertencentes ao conceito de crime. O preceito do novo artigo 386, VI, do Código de Processo Penal, alterado pela Lei 11.690/08, ao determinar a absolvição do acusado quando houver fundada dúvida sobre a existência de circunstâncias que excluam o crime ou isentem o réu de pena, apenas deu mais vazão aos preceitos da presunção de inocência e com ela se conforma.

Essa compreensão da matéria foi recentemente percebida pelo Superior Tribunal de Justiça, aplicando o ônus da prova no processo

59 TARUFFO, Michele. Tres observaciones sobre: por qué un estándar de prueba subjetivo y ambíguo no es un estandar: de Larry Laudan. DOXA: Cuadernos de Filosofía del Derecho. Alicante, n. 28, 2005. p. 117.

60 Bem observa Maurício Zanoide de Moraes o aspecto da presunção de inocência como norma de tratamento relacionada ao ônus probatório no processo penal, afirmando que "o ônus de provar no processo penal é da acusação, uma vez que, partindo o órgão acusador do pressuposto juspolítico do 'estado de inocência' do cidadão, é a ele que caberá demonstrar a sua tese pela culpa do indivíduo e, portanto, caberá a ele o ônus de demonstrar essa tese não pressuposta na Constituição" (ZANOIDE DE MORAES, Maurício. Presunção de Inocência no Processo Penal Brasileiro: análise de sua estrutura normativa para a elaboração legislativa e para a decisão judicial. Rio de Janeiro: Lumen Juris, 2010, p. 462). 
penal conforme a presunção de inocência e desincumbindo o réu de qualquer ônus da prova ${ }^{61}$.

Concernente à regra de julgamento do ônus da prova das excludentes de ilicitude, discute-se, ainda, sobre o grau de convencimento necessário para ocorrer a absolvição pela presença de uma justificante.

Em suma, a questão agora não é mais saber de quem é o ônus de provar a excludente de ilicitude, mas sim, saber se se exige que a defesa provoque o surgimento de uma dúvida sobre a existência da excludente, se bastaria a mera alegação dessa tese ou se sequer o réu precisaria alegá-la, devendo o acusador sempre provar a ausência da justificante ainda que não aventada.

Caso se analise a questão do grau de convencimento de uma excludente de ilicitude pela ótica da presunção de inocência, que provoca um desequilíbrio favorável ao acusado referente à questão probatória, o ônus da prova dessa excludente deveria recair totalmente sobre o acusador, prescindindo-se de alegação pelo réu. Isso porque, ao desincumbir o réu de alegar ou demonstrar uma excludente estará o juiz mantendo o desequilíbrio constitucional instituído pela presunção de inocência em favor daquele.

Por outro lado, exigir que a acusação elabore a minuciosa tarefa de imputar o fato típico juntamente com a demonstração da ausência de qualquer causa excludente de ilicitude ou culpabilidade tornaria o trabalho

${ }^{61}$ STJ, Recurso Especial n ${ }^{0}$ 1.359.446-SP, $6^{\mathrm{a}}$ Turma, rel. Min. Rogerio Schietti Cruz, DJe 28/04/2016: "Registro, ab initio, que a regra do art. 156 do CPP não pode ser considerada de forma isolada, pela mera leitura da primeira parte do dispositivo federal, mas deve ser interpretada de forma sistêmica, de acordo com os ditames dos arts. 41 e 386, VI, do CPP, tendo como norte os princípios reguladores do processo penal condenatório, instrumento concebido para a tutela social da liberdade do indivíduo, orientado pela presunção de inocência e pelo in dubio pro reo, com vistas à melhor reconstrução histórica dos fatos sob julgamento. Deveras, como o réu não manifesta pretensão, apenas nega as circunstâncias narradas na denúncia ou na queixa, o ônus da prova, na ação penal condenatória, é todo da acusação (decorrência natural do princípio do favor rei, bem assim da presunção de inocência, sob a vertente da regra probatória) e o benefício da dúvida deve, sempre, favorecer a defesa. Isso equivale a dizer que a pretensão punitiva estatal somente poderá ser acolhida se o órgão jurisdicional se convencer, com apoio na prova judicializada, de que o réu praticou fato típico, ilícito e culpável, consoante a narrativa acusatória expressa ou implícita, e eventual dúvida relacionada às excludentes conduzem, necessariamente, à absolvição, consoante o art. 386, VI, do CPP”. 
da acusação praticamente inviável, até porque há quatro causas de exclusão da ilicitude e três excludentes de culpabilidade, o que levaria o acusador a, no mínimo, ter que rechaçar de imediato essas sete excludentes, entre as de ilicitude e culpabilidade.

A necessidade, portanto, de se exigir da acusação de antemão a prova da ausência de uma excludente deve advir do caso concreto, não sendo obrigatório em todos os casos discutir a presença ou não de uma excludente. Por exemplo, não há essa necessidade de provar a maioridade penal de uma pessoa aparentemente idosa ${ }^{62}$.

Não obstante essa ressalva, não se pode franquear o princípio da presunção de inocência, que impõe, entre outras coisas, o ônus da prova à parte acusadora, desobrigando o acusado de provar a ausência de uma excludente. Nessa linha, sustenta Luigi Ferrajoli ${ }^{63}$ que "no conflito, o primeiro movimento compete à acusação. Sendo a inocência assistida pelo postulado de sua presunção até prova em contrário, é essa prova contrária que deve ser fornecida por quem a nega formulando a acusação”.

Para tanto, entende-se bastar ao réu alegar a existência da excludente de ilicitude sem que precise carrear provas nesse sentido, nem incutir no julgador uma dúvida razoável sobre a configuração dessa excludente ${ }^{64}$.

62 Essa mesma compressão é concebida por Plínio Antônio Britto Gentil e Bruno Giovannini de Paulo ao expor que "o caminho mais razoável, em tais hipóteses, é avaliar a verossimilhança da alegada excludente. Ou seja, se, nas circunstâncias fáticas concretas, a ocorrência da situação de uma eventual legítima defesa mostra-se como uma possibilidade real, o que deve ser aferido frente ao quadro geral que envolve o cometimento do fato típico. Em tais condições, e se a resposta a esta indagação for afirmativa, o ônus da prova se redireciona. Isto é, ante a verossimilhança de uma justificativa, que afaste a antijuridicidade do fato, caberá à acusação demonstrar a sua não ocorrência. Isto porque é à acusação que incumbe provar a presença de um crime. E por crime se entenda a junção num só evento, ao mesmo tempo, dos requisitos de um fato penalmente típico e da sua antijuridicidade" (GENTIL, Plínio Antônio Britto; PAULO, Bruno Giovannini de. Excludente de ilicitude verossímil e ônus da prova no processo penal. Revista Jurídica, Anápolis, v. 16, n. 2, jul.-dez. 2017. p. 175).

63 FERRAJOLI, Luigi. Direito e Razão: Teoria do garantismo penal. Trad. de Ana Paula Zomer, Fauzi Hassan Choukr, Juarez Tavares e Luiz Flavio Gomes. São Paulo: Revista dos Tribunais, 2002, p. 488.

64 Aury Lopes Jr. afirma que o réu sequer deve alegar a excludente, pois, “a partir do momento em que o imputado é presumidamente inocente, não lhe 
A alegação da excludente de ilicitude pelo réu impõe à acusação o ônus de provar a ausência da excludente ${ }^{65}$.

Por fim, no Projeto do Código de Processo Penal ${ }^{66}$ em trâmite no Congresso Nacional, não utilizará mais a terminologia do art. 156, caput, do Código vigente ("a prova da alegação incumbirá a quem a fizer"), não dispondo de qualquer norma a respeito, mantendo, ainda, no artigo 421, VI, do Código projetado, a absolvição do réu quando houver fundada dúvida sobre a existência de excludente de ilicitude, à semelhança do artigo 386, VI, do Código em vigor. Com isso, reforça-se que o réu não tem o ônus da prova dessas excludentes, encerrando-se a discussão sobre a inadequada pretensão de distribuição dos ônus probatórios entre as partes no processo penal.

Sem dúvida, a alteração de um velho e ambíguo dispositivo legal contribuirá para o abandono dos equívocos a que deu razão, conformando de vez o ônus da prova ao texto constitucional.

incumbe provar absolutamente nada. Existe uma presunção que deve ser destruída pelo acusador, sem que o acusado tenha qualquer dever de contribuir nessa desconstrução" (LOPES JR., Aury. Introdução crítica ao processo penal (Fundamentos da Instrumentalidade garantista). $3^{\mathrm{a}}$ ed. Rio de Janeiro: Lumen Juris, 2005, p. 184). Paulo Rangel sustentando bastar à defesa a mera alegação de uma excludente de ilicitude, afirma que "a defesa poderá ainda, alegar que o réu, efetivamente, atirou na vítima, porém, em legítima defesa. Neste caso, cabe ao Ministério Público o ônus de provar o que descreveu na denúncia, ou seja, um fato criminoso com todas as duas circunstâncias e que, consequentemente, não houve injusta agressão, ou, se existiu esta, que não era atual nem iminente, ou, ainda, não houve uso moderado dos meios e que estes, embora existindo, não eram necessários" (RANGEL, Paulo. Direito Processual Penal. 16. ed., rev., amp., e atual. Rio de Janeiro: Lumen Juris, 2009, pp. 459-460).

65 Em sentido próximo, afirma Gustavo Badaró que "se não foi alegada qualquer excludente pela defesa, não tendo surgido nem mesmo uma dúvida remota sobre sua ocorrência, desnecessária a prova de que o fato não foi acobertado por uma causa de exclusão da antijuridicidade” (BADARÓ, Gustavo H. Ônus...cit., p. 323).

66 O Projeto do Código de Processo Penal, Projeto de Lei PLS 156/09 originouse de Comissão de Juristas nomeada por ato do Presidente do Senado Federal sob a presidência do Ministro do Superior Tribunal de Justiça Hamilton Carvalhido, composta por Antonio Correia, Antonio Magalhães Gomes Filho, Eugênio Pacelli de Oliveira, Fabiano Augusto Martins Silveira, Felix Valois Coelho Júnior, Jacinto Nelson de Miranda Coutinho, Sandro Torres Avelar e Tito Souza do Amaral. O texto, parcialmente alterado, foi aprovado pelo Senado Federal e se encontra na Câmara dos Deputados (PL 8.045/2011). 


\section{Conclusões}

Como fecho conclusivo, admite-se a necessidade de uma revisão das premissas consagradas pela doutrina processual penal sobre o ônus da prova para se manter a coerência na análise crítica sobre uma regra aparentemente pronta e acabada, mas sem o devido rigor teórico. Essa falta de atenção para um tema tão caro ao direito processual penal reflete, de forma incisiva, na prática forense em todos os cantos do país e molda um modelo de processo penal acrítico e sem conformidade constitucional.

O artigo 156, caput, do Código de Processo Penal deve ser objeto de uma interpretação sistemática, evitando-se conclusões simplórias como a afirmação o ônus da prova compete a quem alega, como ocorria no remoto Direito Romano.

A doutrina majoritária, acompanhada pela jurisprudência nacional, apropriou-se da regra de distribuição do ônus da prova prevista no Código de Processo Civil, equiparando autoria e materialidade do fato (tipicidade) com o fato constitutivo do direito do autor e ilicitude ou culpabilidade a um fato impeditivo ou extintivo desse direito. Essa premissa é equivocada por não haver definição precisa de fatos impeditivos, modificativos e extintivos na própria dogmática processual civil.

Tratando-se de uma construção elaborada para o sistema de persecução civil, estrutural e teleologicamente distinto do sistema penal, fica claro um desvirtuamento de sua concepção, impedindo-se sua utilização no processo penal por utilizar a regra de distribuição do ônus da prova entre as partes (artigo 373, I, II, CPC) em local onde não há essa repartição do ônus entre as partes. No processo penal o ônus é somente do acusador.

Afirmar que o ônus da prova de uma excludente de ilicitude é do réu demonstra desconhecimento da teoria do delito e da relação existente entre tipicidade e antijuridicidade, ignorando-se a sede própria para o desenvolvimento desse tema, o direito penal. Isso porque incumbe ao acusador a prova do crime, compreendido como um fato composto de tipicidade, ilicitude e culpabilidade. A quem cabe provar um crime, cabe, por força, provar um fato típico, ilícito e culpável. A afirmação de uma exculpatória não institui um ônus dessa prova ao acusado, mas a própria contraprova do fato constitutivo. 
Ademais, nessa importação acrítica de lições civilistas para o processo penal, olvidou-se que nesse ramo existe a garantia juspolítica da presunção de inocência em favor do réu que, em sua face probatória, gera um desequilíbrio da relação processual em desfavor da acusação, devendo, então, suportar todo o ônus da prova do crime que imputa.

Assim, por todos os ângulos que se veja, o ônus da prova das excludentes de ilicitude e culpabilidade devem ser suportados pelo acusador, não podendo haver espaço para exceções a essa regra.

\section{ReferênCIAs Bibliográficas}

BADARÓ, Gustavo Henrique Righi Ivahy. Ônus da prova no processo penal. São Paulo: RT, 2003.

BARBOSA MOREIRA, José Carlos. Julgamento e ônus da prova. In: BARBOSA MOREIRA, José Carlos. Temas de Direito Processual. $2^{\mathrm{a}}$ ed. ( $2^{\mathrm{a}}$ serie). São Paulo: Saraiva, 1988.

BITENCOURT, Cezar Roberto. Tratado de Direito Penal, parte geral, v. I. $9^{a}$ ed. São Paulo: Saraiva, 2004.

BUENO, Cassio Scarpinella. Curso sistematizado de direito processual civil. São Paulo: Saraiva, 2007, v. I.

CEREZO MIR, José. Derecho penal: parte general: lecciones 26-40. 2. ed. Madrid: Universidad Nacional de Educación a Distancia, 2000.

CHIOVENDA, Giuseppe. Instituições de Direito Processual Civil. Tradução da $2^{\mathrm{a}}$ ed. Italiana de J. Guimarães Menegale. São Paulo: Saraiva, 1969, v. II.

CINTRA, Antônio Carlos de Araújo. Comentários ao Código de Processo Civil. $3^{\mathrm{a}}$ ed. rev. e atual. Rio de Janeiro: Forense, 2008.

DINAMARCO, Cândido Rangel. A instrumentalidade do processo. $12^{\mathrm{a}}$ ed. rev. e atual. São Paulo: Malheiros, 2005.

DINAMARCO, Cândido Rangel. Instituições de Direito Processual Civil. $3^{\mathrm{a}}$ ed. rev. e atual. São Paulo: Malheiros, 2003, v. III.

FERRAJOLI, Luigi. Direito e Razão: Teoria do garantismo penal. Trad. de Ana Paula Zomer, Fauzi Hassan Choukr, Juarez Tavares e Luiz Flavio Gomes. São Paulo: Revista dos Tribunais, 2002. 
GENTIL, Plínio Antônio Britto; PAULO, Bruno Giovannini de. Excludente de ilicitude verossímil e ônus da prova no processo penal. Revista Jurídica, Anápolis, v. 16, n. 2, p. 170-188, jul.-dez. 2017. http://dx.doi.org/10.29248/2236-5788. 2017v17i2.p170-188

GOLDSCHMIDT, James. Teoria geral do processo. Trad. Leandro Farina. Leme: Fórum, 2006.

GRECO FILHO, Vicente. Direito Processual Civil Brasileiro. v. II. 16a ed. São Paulo: Saraiva, 2003.

HORTA, Frederico Gomes de Almeida. Do ônus da prova dos elementos de valoração global do fato: análise crítica de precedente do Superior Tribunal de Justiça (STJ, HC 194.225). Revista Brasileira de Ciências Criminais, São Paulo, a. 21, v. 104, p. 173-202, set./out. 2013.

JARDIM, Afrânio Silva. Direito Processual Penal. 12. ed. Rio de Janeiro: Forense, 2003.

KARAM, Maria Lucia. Sobre o ônus da prova na ação penal condenatória. Revista Brasileira de Ciências Criminais, São Paulo, v. 9, n. 35, jul./set. 2001.

LIEBMAN, Enrico Tullio. Manual de Processo Civil. $2^{\mathrm{a}}$ ed. Tradução de Cândido R. Dinamarco. Rio de Janeiro: Forense, 1985.

LIMA, Marcellus Polastri. A Prova penal. $2^{\mathrm{a}}$ ed. Rio de Janeiro: Lumen Juris, 2003.

LOPES JUNIOR, Aury. Introdução crítica ao processo penal (Fundamentos da Instrumentalidade garantista). $3^{\mathrm{a}}$ ed. Rio de Janeiro: Lumen Juris, 2005.

LOPES JUNIOR, Aury. Réu não deve ser obrigado a provar causa de exclusão da ilicitude. Revista Magister de Direito Penal e Processual Penal, Porto Alegre, v. 12, n. 67, p. 43-47., ago./set. 2015.

LOPES JUNIOR, Aury; SILVA, Pablo Rodrigo Alflen da. Breves apontamentos in memoriam a James Goldschmidt e a incompreendida concepção de processo como "situação jurídica". Discursos Sediciosos: crime, direito e sociedade, Rio de Janeiro, v. 17, n. 19/20, p. 35-52, $1^{\circ}$ e $2^{\circ}$ sem., 2012.

MALATESTA, Nicola Framarino Del. A lógica das provas em matéria criminal, v. I. Tradução de Alexandre Correia. São Paulo: Saraiva, 1960.

MARINONI, Luiz Guilherme; ARENHART, Sérgio Cruz. Curso de Processo Civil: Processo de Conhecimento. $7^{\mathrm{a}}$ ed. São Paulo: Revista dos Tribunais, 2008, v. II.

MARINONI, Luiz Guilherme; ARENHART, Sérgio Cruz; MITIDIERO, Daniel. Novo código de processo civil comentado. $2^{\mathrm{a}}$ ed. São Paulo: RT, 2016. 
MARQUES, José Frederico. Elementos de Direito Processual Penal. $2^{\mathrm{a}}$ ed. Campinas: Millennium, 2000, v. II.

MARQUES, José Frederico. Manual de Direito Processual Civil. $2^{\mathrm{a}}$ ed. Campinas: Millennium, 2000, v. II.

MEZGER, Edmund. Tratado de derecho penal. $2^{\mathrm{a}}$ ed. Madrid: RDP, 1955, t. I, p. 376. NAVARRETE, Miguel Polaino. Derecho penal: parte general. Barcelona, Ed. Bosch, 2000, v. I, t. II.

NEVES, Daniel. Novo código de processo civil comentado. Salvador: Juspodivm, 2016.

NUCCI, Guilherme de Souza. O valor da confissão como meio de prova no Processo Penal. 2. ed. São Paulo: Revista dos Tribunais, 1999.

NUCCI, Guilherme de Souza. Provas no processo penal. São Paulo: Revista dos Tribunais, 2009.

OLIVEIRA, Eugenio Pacelli de. Curso de Processo Penal. $10^{\mathrm{a}}$ ed. Rio de Janeiro: Lumen Juris, 2008.

PEDROSO, Fernando de Almeida. A Prova Penal. $2^{\mathrm{a}}$ ed. São Paulo: Revista dos Tribunais, 2005.

PONTES DE MIRANDA, Francisco Cavalcanti. Comentários ao Código de Processo Civil. 3. ed. rev. e aum. Rio de Janeiro: Forense, 2001, tomo IV.

RANGEL, Paulo. Direito Processual Penal. 16a ed. Rio de Janeiro: Lumen Juris, 2009. REALE JUNIOR, Miguel. Antijuridicidade concreta. São Paulo: José Bushatsky, 1974. SANTOS, Juarez Cirino dos. Direito penal: parte geral. $2^{\mathrm{a}}$ ed. Curitiba: ICPC; Lumen Juris, 2007.

SANTOS, Moacyr Amaral. Primeiras linhas de Direito Processual Civil. $23^{\mathrm{a}}$ ed. rev. e atual. São Paulo: Saraiva, 2004.

SILVA, Ovídio Baptista da. Curso de Processo Civil. 5a ed. São Paulo: Revista dos Tribunais, 2000.

TARUFFO, Michele. A prova. São Paulo: Marcial Pons, 2014.

TARUFFO, Michele. Tres observaciones sobre: por qué un estándar de prueba subjetivo y ambíguo no es un estandar: de Larry Laudan. DOXA: Cuadernos de Filosofía del Derecho, Alicante, n. 28. 2005. https://doi.org/10.14198/doxa2005.28.09 
THEODORO JUNIOR, Humberto. Curso de direito processual civil, v. I. $44^{\mathrm{a}}$ ed. Rio de Janeiro: Forense, 2006.

TORNAGHI, Helio. Curso de Processo Penal, São Paulo: Saraiva, 1989, v. I.

ZAFFARONI, Eugenio Raul. Manual de Derecho Penal. México: Cardenas, 1988.

ZANOIDE DE MORAES, Maurício. Presunção de Inocência no Processo Penal Brasileiro: análise de sua estrutura normativa para a elaboração legislativa e para a decisão judicial. Rio de Janeiro: Lumen Juris, 2010.

\section{DicIONÁRIOS}

Academia Brasileira de Letras. Dicionário Escolar da Língua Portuguesa. 2. ed. São Paulo: Companhia Editora Nacional, 2008.

FERREIRA, Aurélio Buarque de Holanda. Minidicionário da língua portuguesa, 4. ed. Rio de Janeiro: Nova Fronteira, 2001.

\section{Informações adicionais e declarações dos autores (integridade científica)}

Declaração de conflito de interesses (conflict of interest declaration): o autor confirma que não há conflitos de interesse na realização das pesquisas expostas e na redação deste artigo.

Declaração de autoria e especificação das contribuições (declaration of authorship): todas e somente as pessoas que atendem os requisitos de autoria deste artigo estão listadas como autores; todos os coautores se responsabilizam integralmente por este trabalho em sua totalidade.

Declaração de ineditismo e originalidade (declaration of originality): o autor assegura que o texto aqui publicado não foi divulgado anteriormente em outro meio e que futura republicação somente se realizará com a indicação expressa da referência desta publicação original; também atesta que não há plágio de terceiros ou autoplágio. 
Dados do processo editorial

(http://www.ibraspp.com.br/revista/index.php/RBDPP/about/editorialPolicies)

- Recebido em: 10/12/2017

- Controle preliminar e verificação de plágio: 19/12/2017

- Avaliação 1: 21/12/2017

- Avaliação 2: 05/01/2018

- Avaliação 3: 08/01/2018

- Avaliação 4: 09/01/2018

- Decisão editorial preliminar: 10/01/2018

- Retorno rodada de correções: 04/02/2018

- Decisão editorial final: 05/02/2018

\section{Equipe editorial envolvida}

- Editor-chefe: 1 (VGV)

- Editor-associado: 1 (GHB)

- Revisores: 4

\section{COMO CITAR ESTE EDITORIAL:}

NOGUEIRA, Rafael Fecury. Ônus da prova das excludentes de ilicitude no processo penal e a necessidade de rompimento com a sua matriz civilista. Revista Brasileira de Direito Processual Penal, Porto Alegre, vol. 4, n. 1, p. 243-275, jan./abr. 2018. https://doi.org/10.22197/rbdpp.v4i1.124

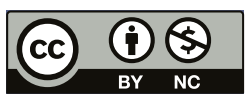

Esta obra está licenciada com uma Licença Creative Commons Atribuição-NãoComercial 4.0 Internacional. 